\author{
Eleonora Gonda-Soroczyńska* \\ Maria Heldak** \\ Wrocław University of Environmental And Life Sciences
}

\title{
THE TOURIST ATTRACTIVENESS OF RURAL SPAS ON THE EXAMPLE OF PRZERZECZYN-ZDRÓJ AND DLUGOPOLE-ZDRÓJ
}

\begin{abstract}
The conducted research involves an attempt at evaluating the attractiveness of rural spas using the example of two Lower Silesian villages - Przerzeczyn-Zdrój and Długopole-Zdrój. The authors pursue the answer to the following question: "Can rural spas be evaluated in the context of attractiveness, as is the case with urban ones? What guidelines can be used for the purpose of such an evaluation?" This is followed by an initial formulation of the elements determining the attractiveness of a spa, which include: the location of the spa in the context of important road, railway and bus passageways (accessibility); topographic location; the curative (medicinal) climate; the existence of curative materials (curative mineral waters, peloids etc.); the types of curative treatment available; available night lodgings in sanatoriums, spa hospitals, hotels, pensions, motels, inns; spa well-rooms; Spa Houses, green areas (including Spa Parks and forests); amphitheatres; bandshells; Spa Theatres; restaurants, cafés, bars and other gastronomic outlets; tourist attractions; non-curative functions; non-curative tourist infrastructure; the types of treated illnesses; the architectural and urban consistency of curative facilities; public utility infrastructure; the quality of the environment.
\end{abstract}

Keywords: village, Przerzeczyn-Zdrój, Długopole-Zdrój, spa, curative function, attractiveness, multifunctionality

* E-mail address: eleonora.gonda-soroczynska@up.wroc.pl.

** E-mail address: maria.heldak@up.wroc.pl. 


\section{Introduction}

When discussing the tourist attractiveness of rural spas one should reflect on whether it may be measured using the same guidelines used in respect to curative centres located in both small and large cities. ${ }^{1}$ The indicators available for the tourist function have a purpose in deliberations on the subject of spa attractiveness. The concept of the tourist and curative function indicator has already been established by other scientists. ${ }^{2}$ Despite the fact that rural spas follow their own set of principles, their multifunctional nature - an indispensable element of their functioning and potential development - should be utilised within a market economy. ${ }^{3}$ The development of tourist and spa areas has been provided with a theoretical description in the concepts of S.C. Plog and R.W. Butler. ${ }^{4}$ The multifunctional character of spa towns results from the need to introduce new, attractive functions apart from the typical curative function, addressed to the tourist in the broadest sense of the term, not exclusively to patients. These include the sports and recreation function or the spa and wellness function, ${ }^{5}$ as well as functions related to gastronomy, hotel accommodation, leisure, recurring events and tourist attractions. The sports and recreation function mostly involves

Z. Kruczek, Atrakcje turystyczne. Fenomen typologii, metody badań (Tourist attractions. The phenomena of their typology and research methods), "Monograph", No. 10, Proksenia, Kraków, 2011, p. 18; Z. Kruczek, Atrakcyjność turystyczna uzdrowisk karpackich (The touristical attractiveness of Carpathian spas), in: Uzdrowiska i ich funkcja turystyczno-lecznicza (Spas and their touristical-curative function), "Monograph", No. 13, Proksenia, Kraków 2012, pp. 59-72.

2 A.R. Szromek, Wskaźniki funkcji turystycznej. Koncepcja wskaźnika funkcji turystycznej $i$ uzdrowiskowej (The tourist function indicators. The concept of the tourist and curative function indicator), Silesian University of Technology Publishing House, Gliwice 2012, p. 199.

A. Gotowt-Jeziorska, J. Wyrzykowski, Turystyka a uzdrowiska (Tourism and spas), Polish Tourist Association, Warszawa 2005.

4 A.R. Szromek, Rozwój obszarów turystycznych i uzdrowiskowych $w$ koncepcjach S.C. Ploga i R.W. Butlera (The development of touristical and curative areas in the concepts of S.C. Plog and R.W. Butler), "The Silesian University of Technology Research Bulletins", Organisation and Management Section, Vol. 54/2010, Gliwice, pp. 305-322; R.W. Butler, The concept of the tourism area cycle evolution: implications for management of resources, "The Canadian Geographers" 1980, Vol. 24/1, pp. 5-12.

5 A. Hadzik et al., Konkurencyjność produktu turystyki uzdrowiska Kolobrzeg (The competitiveness of the tourism product of the Kolobrzeg spa). Znaczenie innowacyjnych ustug i infrastruktury prozdrowotnej (The importance behind innovative services and pro-health infrastructure), Acta Scientiarum Polonorum- Oeconomia No. 9 (4), Tourism Experts Board, Warsaw University of Life Sciences, Warszawa 2010 pp. 153-164. 
indoor and outdoor swimming pools, various types of sports fields, cycling and walking routes, alpine slides, ski pistes and ski lifts. ${ }^{6}$ The leisure function serves to stimulate social and economic development. The objective development of the leisure tourist function requires an increased economic effort. ${ }^{7}$ Leisure related costs are constantly growing. An increasing number of people, including youth, is interested in rest and relaxation at a spa, even for a short period of time. Regardless of their age, contemporary people wish not only to be healthier, but prettier as well, thus the spa and wellness function comes into play. ${ }^{8}$ Spa and wellness centres are more commonly found in small rural or urban settlements (e.g. Długopole-Zdrój). They usually operate as "renewal centres", with medical treatment serving a supplementary role. The attractiveness of a spa rises as it introduces spa and wellness related services. ${ }^{9}$ A spa of this type may be considered not only a health centre, but also as a beauty centre. The gastronomic function is most commonly combined with the hotel function, though quite often it also functions on its own. ${ }^{10}$ Gastronomy serves as an important stimulus for the growth of tourism, as it has a direct impact on the size of tourist movement and the quality of its management. The important character of gastronomic services offered to tourists mainly revolves around the fact that they serve as a substitute for food-related services performed at home by the tourists themselves. ${ }^{11}$

6 R.W. Butler, The concept of the tourism area cycle evolution: implications for management of resources, "The Canadian Geographers" 1980, Vol. 24/1, pp. 5-12.

7 T. Iwanek, Turystyka uzdrowiskowa $w$ gospodarce regionu i kraju (Curative tourism in the economy of the region and the state), "Edukacja" College of Management Publication House, Monographs - Joint Publications at the "Edukacja" College of Management in Wrocław, Wrocław 2006.

8 M. Łazarek, R. Łazarek, Uzdrowiska w Europie. Teraźniejszość i rys historyczny (Spas in Europe. Contemporary times and a historical outline), Vincent Pol University in Lublin Publishing House, Lublin 2007; A. Mroczek-Czetwertyńska, A. Rapacz, Popyt na ustugi Spa\&Wellness i możliwości jego zaspokojenia na przykładzie Dolnego Śląska (The demand for Spa \& Wellness services and the possibilities for its fulfilment using the example of Lower Silesia), University of Szczecin Research Bulletin, Economic issues related to Services, No 84 (Tourist demand. Consumption-segmentation-markets), Szczecin, 2012, pp. 579-592.

9 N. Sallmann, Megatrend wellness \& spa (The wellness\&spa megatrend), PAG, Kraków 2010, pp. 78-79.

10 A. Kowalczyk, M. Derek, Zagospodarowanie turystyczne (Tourism management), Wydawnictwo Naukowe PWN, Warszawa 2010.

11 W.W. Gaworecki, Turystyka (Tourism), Polskie Wydawnictwo Ekonomiczne, Warszawa 2003. 
Curative spa treatment is performed with the use of spa treatment equipment, which plays a major role in the "ideal" spa model. These include natural therapy resorts, spa well-rooms, thorn houses, parks - including spa, parks - fitness trails, converted sea coast sections, medicinal and rehabilitative therapeutic pools, arranged underground headings usually located in the " $\mathrm{A}$ " curative protection zone. These elements constitute the spa infrastructure ${ }^{12}$, formed throughout different historical periods, having a profound impact on the tourist and representing the diverse standard of a given spa establishment. It also serves as an important element in the evaluation of the attractiveness of a spa. This type of infrastructure is usually less extensive in rural spas, than it is in urban ones.

\section{Scope of the problem}

This study is an attempt at indicating the guidelines which need to be taken into account when evaluating the attractiveness of rural spas. The research involves two examples of Lower Silesian villages: Przerzeczyn-Zdrój and Długopole-Zdrój, located in different topographic conditions. They are comparable in size. Since currently rural spas in Poland do not make use of highly developed spa infrastructure or complex communication networks the authoress has introduced the division to rural and urban spas. The technical, social and public utility infrastructure of a rural spa is often less impressive, while its surroundings differ greatly from those of an urban centre (including both small or large cities). ${ }^{13}$ It is also visited by a smaller number of patients, tourists in the general sense, outside visitors and local residents. The study includes a set of guidelines determining the attractiveness of a spa, some of which include: the location of the spa in the context of key road, railway and bus passageways (accessibility); its location in the topographic con-

12 M. Januszewska, Zróżnicowanie przestrzenne infrastruktury uzdrowiskowej na Dolnym Ślasku (The spatial diversity of curative infrastructure in Lower Silesia), Research Papers No. 967, Wrocław University of Economics, Wrocław 2002, pp. 191-204.

13 J. Petryszyn, E. Zuzańska-Żyśko, Od funkcji przemystowej do turystycznej - przykład Ustronia (From the industrial to the tourist function - the example of Ustron'), in: The tourist function of cities. $11^{\text {th }}$ Urban Knowledge Seminar, ed. I. Jażdżewska, Łódź University Publishing House, Łódź 2008, pp. 133-144; E. Zuzańska-Żyśko, Funkcja turystyczna małych miast województwa śląskiego (The tourist function of smaller cities in the Silesia Province), in: Ksztaltowanie funkcji turystycznych w miejscowościach uzdrowiskowych (Developing tourist functions in spa towns), ed. E. Rydz, PAP, Słupsk 2005, pp. 71-87. 
text; the curative (medicinal) climate; the existence of curative materials (curative mineral waters, peloids etc.); the type and number of available curative treatment; available night lodgings in sanatoriums, spa hospitals, hotels, pensions, motels, inns (number and standard); spa well-rooms; Spa Houses, green areas (including Spa Parks and forests located in the spa or in its vicinity); amphitheatres; bandshells; Spa Theatres; restaurants, cafés, bars and other gastronomic outlets; tourist attractions; non-curative functions; non-curative tourist infrastructure; the types of treated illnesses; the architectural and urban consistency of curative facilities; public utility infrastructure; the quality of the environment. Establishing an "ideal" model of a contemporary Polish rural spa using the currently available research results is recommended for future research.

The authoress has formulated the following research thesis: "What kinds of guidelines influence the attractiveness of a rural spa?"

\section{Essential information regarding the studied spa towns}

Przerzeczyn-Zdrój (German: Bad Dirsdorf) is a spa (multistreet) village in the South-Western Poland, in the Lower Silesian Province, the Dzierżoniów County and the Niemcza municipality. It is located next to a major communication route, i.e. National Route 8 connecting Wrocław and Kudowa-Zdrój. The village is divided across both by a regional road leading to Dzierżoniów and a number of local roads. New single-family structures have been raised near these main communication passageways, especially in the last decade.

The town is located at the foot of the Sudetes and surrounded by the scarcely forested Niemczańsko-Strzelińskie Hills near the source of the River Ślęza. The town has a population of circa 700 (data from 2006). The spa comprises four sanatoriums with 162 beds.

The first mention of Przerzeczyn can be traced back to the year 1264 . The town $>$ initial name was Pyrzyce (the Slavic etymology). It has been renamed Bad Dirsdorf in the 1930s. The three former administrative names included: NiederDirsdorf, OberDirsdorf and Dirsdorf. The name Przerzeczyn-Zdrój was officially introduced in $1946 .{ }^{14}$

14 B. Mirek, Przerzeczyn-Zdrój - o mojej wsi opowieść (Przerzeczyn-Zdrój-a tale of my village), Wrocław 2004. 
As a spa, Przerzeczyn began its operations in the 19th century, after Friedrich August von Pfeil (1785-1830), the owner of Lower Przerzeczyn, had discovered mineral waters in the area. The spa was constructed by Friedrich Ludwig von Pfeil (1780-1857), the owner of Upper Przerzeczyn. The newfound spring (discovered while searching for chrysoprase deposits) known as "Rozrabiacz" ("Troublemaker") or "Śmierdziel" ("Stinker", due to its strong smell of sulfur compounds) was used in the treatment of various illnesses (including ulcers). The year 1802 is considered the founding date of the spa in Przerzeczyn, with the year 1827 marking the beginning of its commercial activity. 1840 saw the construction of the Grand Spa House with 17 rooms for patients. It was accompanied by a separate building with showers and water heated by steam pumps, as well as the "Namiot" ("Tent") restaurant and a promenade. A special folder provided a description of the spa and a price list for services related to accommodation and treatment. The number of patients increased every year, with more people interested than there were rooms for. Consequently, a number of private quarters became available in the village. In 1936 the spa had the following spa infrastructure at its disposal: sanatoriums, the Spa House, the hotel, a restaurant with a billiard hall and a reading room, a square with deckchairs, a spring in an interesting exposition, part of the Spa Park and a dance hall for 100 people. The spa served as a treatment and rehabilitation centre for German soldiers during WWII. After the war, in the spring of 1946, the spa resumed its curative services with circa 60 beds available. ${ }^{15}$ The community house built in the 1950s with a theatre room and a cinema with 150 seats is currently a high-standard pension (with a swimming pool).

In the 1980s works began on a sewage plant and a new sanatorium catering outlet for 300 persons (commissioned in 1990). At the time of governmental transformations in Poland both the spa and village were connected to a gas supply and the standard of the services provided to the patients improved. Starting from the 1990s, the spa offered around 30 different types of curative treatment, including traditional mineral radioactive and sulphidic baths, hydro massage, pearl baths, peloid wraps (using the best peloids available in the country), inhalations, massages, curative gymnastics, scotch douches, cryotherapy, saunas

15 A.M. Soroczyńska, Walory środowiskowe najmniejszego uzdrowiska w Polsce, Przerzeczyna-Zdrój (The environmental values of the smallest spa in Poland-Przerzeczyn-Zdrój), Infrastruktura i Ekologia Terenów Wiejskich Vol. 10, PAN, The Rural Technical Infrastructure Commission, Kraków 2011, pp. 133-146. 
and a swimming pool (since 2003). In 1999 the enterprise was transformed into a limited liability company State Treasury as its sole shareholder. In 2011 PCZ S.A. with its registered office in Wrocław signed a purchase contract for $85.72 \%$ of the company's issued capital from the State Treasury.

A new spa complex with a hospital is currently under construction (for 25 million PLN). Its completion will allow for the capacity of the sanatorium to be increased up to 400 rooms for patients. Another planned addition is a cardiological inpatient rehabilitation unit for systemic rehabilitation in stationary conditions, to be used for rehabilitation, physiotherapy, diagnostic studies and their respective supplementary services. The PCZ Polskie Uzdrowisko Ciepłowody Przerzeczyn-Zdrój is one of the smallest facilities of this type in the country. Plans exist of strengthening its position on the curative market by means of this investment as well as of becoming part of the medium-sized Polish spas group.

Długopole-Zdrój (German: Bad Langenau) is a village (570 residents, data from 1998) located in the Lower Silesian Province, in the Kłodzko County and the Bystrzyca Kłodzka municipality, in the Central Sudetes, in the southern part of the Kłodzko Valley, in the watershed of the upper course of the River Nysa Kłodzka, at an altitude of 300 to 900 meters m.a.s.l., between the Bystrzyckie Mountains in the west and the Śnieżnik Mountains in the east. The region is attractive for tourists, with a diversified natural topography, a mild submountaine climate (bioclimatic submontane and montane zone 6, medium stimulus bioclimate type, periodically high stimulus type). The town is the smallest spa in the Kłodzko Land. It stretches for circa $1.0 \mathrm{~km}$, mainly along the left shore of the Nysa Kłodzka (small linear village). The spa directly shares its borders with buildings in Długopole Dolne in the north and Długopole Górne in the south. The climatic conditions in the area furthers rest, rehabilitation and treatment. The architecture of Długopole-Zdrój consists mostly of the garden-city villa type built up, typical of spas. It forms a consistent complex with features characteristic for the resort architecture of previous historical periods. Many pensions and residences from the 1850s and the beginning of the 20th century still remain in the village. There is a vast Spa Park located in the centre of the spa (it underwent a complex modernisation in the years 2010-2011) with numerous elements of small garden architecture (avenues, wall slopes, terrain stairs). The park is enriched with beautiful specimens of historic trees: pines, yews, sycamores, lime trees and maples. 
In order to protect the natural materials required to pursue and develop spa treatment and to develop other environmental factors for the Długopole-Zdrój, three curative protection zones have been established, including the following: ${ }^{16}$ the "A" area (zone) of curative protection (this area is reserved only for equipment and structures related to spa treatment); the "B" curative protection area (zone) adjacent to zone "A" and surrounding it, dedicated to service, tourist, recreational, sports-related and public utility structures, residential housing and other structures related to the fulfillment of the needs of people from this area, with little negative impact on the curative features of the spa or the curative protection zone as well as non-intrusive towards the treatment process, or located within the borders of a national park of nature reserve, or constitutes a forest, sea or lake; a buffer zone for area "A"); the "C" curative protection area (zone), which serves as a buffer zone for areas " $\mathrm{A}$ " and "B" (an area influencing the retaining of climatic and landscape-related values and the protection of natural deposits of curative materials).

\section{Selected elements influencing the attractiveness of Przerzeczyn-Zdrój and Długopole-Zdrój. Curative materials}

The basic curative materials of Przerzeczyn-Zdrój include curative natural mineral waters (sulphidic, radioactive and ferruginous) and the climate itself.

Radioactive-sulphidic water with complex medicinal properties is used in balneotherapy. Water rich in magnesium and calcium is used in drinking therapy. There are 3 curative water springs located in the spa which can be used for treatment. These include: the borehole no. 2 with the specific (low mineralised) water $0.043 \%$, the radon water containing hydrogen sulfide in the exploitable yield of $2.27 \mathrm{~m} / \mathrm{h}$; the borehole no. 8 with the specific (low mineralised) water $0.055 \%$, the radon water (currently inoperational) in the exploitable yield of $2.4 \mathrm{~m} / \mathrm{h}$; the borehole no. 9 with the specific (low mineralised) water $0.048 \%$, the radon water in the exploitable yield of $3.0 \mathrm{~m}^{3} / \mathrm{h}$.

Przerzeczyn-Zdrój is one of the few places in the world which uses radioactive water treatment.

\footnotetext{
16 Długopole-Zdrój Spa Statement.
} 
The treatment complex is located in the natural therapy resort which offers circa 30 types of treatment. These are divided into five groups: the treatment with balneological materials, i.e. water, peloids, inhalations; current treatment; massages; rehabilitation; light therapy. The illnesses treated at the spa include: rheumatic disorders, osteoarthritis, neuralgia, sciatic and brachial neuritis, posttraumatic disorders, osteoporosis, upper respiratory tract diseases. The treatment methods include whirlpool baths, pearl baths in radon and sulphidic water, dry, whirlpool and vibration massages, peloid wraps and compresses, physical therapy, inhalations and light therapy, rehabilitation pool therapy, aromatherapy.

The climate is submontane, of the medium stimulus type, warm and mild due to a valley-based location. Microclimatic zones exist in the area. ${ }^{17}$ The medicinal properties of the climate of Przerzeczyn-Zdrój have been confirmed in 2009 by the Stanisław Leszczyński Institute of Geography and Spatial Organisation.

Curative water is known to have existed in Długopole-Zdrój since the 16th century. Its presence is a result of the dislocation of Precambrian mica shales. There are three springs of curative water with intakes in an old 17 meters deep mining tunnel. These are called "Emilia", "Kazimierz" and "Renata." The springs are self-activated. The active yield for "Renata" equals $0.84 \mathrm{~m}^{3} / \mathrm{h}$, while its exploitable yield is $1.07 \mathrm{~m}^{3} / \mathrm{h}$. The water from this spring is $0.13 \%$ mineral water, rich in sodium bicarbonate, calcium, magnesium, sodium, silicon, iron; The active yield for "Emilia" equals $0.96 \mathrm{~m}^{3} / \mathrm{h}$, while its exploitable yield is $0.47 \mathrm{~m}^{3} / \mathrm{h}$. The water in this spring is low mineralized: $0.08 \%$ with hydrogen carbonate, calcium, magnesium, radon, iron; The active yield for "Kazimierz" equals $0,15 \mathrm{~m}^{3} / \mathrm{h}$, while its exploitable yield is $0,41 \mathrm{~m}^{3} / \mathrm{h}$. The water in this spring is $0.11 \%$ mineral water with hydrogen carbonate, calcium, magnesium, sodium and iron. The curative water resources in Długopole-Zdrój should be considered practically inexhaustible, after assuming that they are atmospheric waters that constantly refill themselves and undergo constant mineralization with the contribution of the $\mathrm{CO}_{2}$ that is still flowing from the depths of the earth. The chemism of these waters and their output may be subject to minor periodic changes depending on atmospheric conditions.

17 T. Kozłowska-Szczęsna et al., Bioklimat uzdrowisk polskich i możliwości jego wykorzystania $w$ lecznictwie (The bioclimate of Polish spas and the possibilities for its utilisation), PAN Institute of Geography and Spatial Organization, “Monograph”, No. 3, Warszawa 2002. 


\section{Natural environment as a source of potential and a guideline for the spa's attractiveness}

Przerzeczyn-Zdrój is surrounded by fields, meadows and small groves. The small Spa Park with a fitness trail, a club/café and a library for patients as well as a pergola and a square for playing chess is characterised both by contrasts in air temperature per 24 hours smaller than those typical of the centre of the spa, a uniform heating and cooling rate and the highest temperature values during nighttime. The walking space surrounding the spa are located in the open. It is also where the increase in air temperature is the most rapid when compared to other areas. On the other hand, the heating rate is the lowest here. The Spa Park is a geometrical structure. It is formed by perpendicular, generally singlespecies avenues, with rectangular lawn isles in between. The species composition of the Spa Park is unimpressive and includes e.g. the small-leaved lime, the silver maple, the douglas fir and the Norway spruce.

Some noteworthy elements of the environmental potential of the Upper Przerzeczyn include: an earth dike with Lombardian poplars near a pond located in the vicinity of the neoclassicist von Pfeil family palace; the 18th century park surrounding the residence, with plane trees, cucumber trees, black pines and old oaks which form avenues; the English style park in the Lower Przerzeczyn (the part of the village stretching from the Wrockaw-Kudowa road to the church) with an area of 3 ha and 200-year-old specimens of tulip trees, purple leaf and cut leaf beeches, yews, Swiss pines, plane trees, oaks, lime trees and Chinese junipers. This makes a total of 49 species, including 24 species of foreign origin.

The Bystrzyca Kłodzka municipality is one of the most forested regions in Poland. The forests cover the area of approximately $154 \mathrm{~km}^{2}$, that is, almost $46 \%$ of the total municipality area. This has a beneficial impact on the spa's functioning and local climate. The natural environment constitutes the area's greatest potential as regards the broadly understood tourism development. The Bystrzyca Kłodzka municipality contains the Śnieżnik Landscape Park, the Wilczki Waterfall Reserve, 1 protected landscape area, 1 landscape park, 1 nature reserve and 22 natural monuments. There are over $360 \mathrm{~km}$ of tourist routes leading through the Śnieżnik Landscape Park.

There are five reserves in the Śnieżnik Landscape Park: "Śnieżnik Kłodzki”, "Nowa Morawa", "Puszcza Śnieżnej Białki”, "Wodospad Wilczki”, and "Jaskinia Niedźwiedzia." There are numerous species of flora and fauna within the park. 
One noteworthy area located in the Bystrzyca Kłodzka municipality is the Dzika Orlica - a form of protection included in the Natura 2000 network a special area of habitat protection (Habitats Directive). It stretches across 539.7 ha. Its formal status has been confirmed by a European Commission Decision. The area includes a fragment of the river valley of the River Dzika Orlica in its upper course and is shaped into a narrow belt.

The protective zone of the Długopole-Zdrój spa contains curative forests representative of the group of special purpose forests.

One particular spa's attraction is the Spa Park subject to general revitalisation (at the cost of over 4 million PLN, with 3 million PLN funded by the European Union) between 2010-2011. As a result, walking avenues have been delineated anew, while the cave with a spring of curative water, the pond with its gazebo, and the amphitheater along with the auditorium have all been reconstructed. One addition includes a wooden platform with a pergola, fountain and a place to rest. The new lighting has also been installed along with benches and vegetation enhancing the charm of this part of the spa.

\section{Curative infrastructure}

Part of Przerzeczyn-Zdrój is located outside the residential area, near the borders of the village, not far from the nearby green areas. The spa consists of 4 sanatoriums with 162 beds, a natural therapy resort, a library, a café and a Spa Park with the "Forsycja" (Forsythia) fitness trail (60 lodgings in single and double rooms with a full sanitary unit and superior standard rooms and apartments. One part of the building is two stories high, while another -three stories high. The roof is a shingle hip roof with many dormers. The structure has undergone a complex modernization and is now divided into: the "Akacja" ("Acacia:) sanatorium, with single, double and triple rooms, a full sanitary unit and basic standard rooms without full sanitary units. A natural therapy resort is located in the sanatorium. The building is prewar, two-story-high, with a shingle pitched roof); and the "Buk" ("Beech") sanatorium, with single, double and triple rooms, a full sanitary unit and basic standard rooms without full sanitary units. The entire prewar building is three stories high and has a converted loft, its roof being shingle pitch. The interior of the building has, too, been renovated (the exterior elevation and the roof require renovation). Next, there is also the "Cis" ("Yew") sanatorium 
(with single, double, triple and quadruple rooms, basic standard, without full sanitary units and rooms with full sanitary units situated in the prewar building with a basement, two stories and a converted loft. The roof (in need of renovation) is a shingle pitched roof with a large dormer on the front side. The ,Jasiek” apartment is a single building with single and double rooms with full sanitary units.

The spa offers a state-of-the-art pool for rehabilitation and treatment $(12 \mathrm{~m} \times 5.5 \mathrm{~m}$ and maximum depth of 1.5 meters), fully adapted for the disabled. It is also equipped in hydro massage and hydro/water massage units, a unit for upstream swimming and cumulative massage, and two upper stream units for neck massages with an automated time counter which switches between the upper, lateral and bottom jets.

Due to the relatively small number of curative infrastructure buildings in the village, its residents offer accommodation to tourists in private houses, especially the new ones. The largest number of such new structures is located along the National Road 8 to Wrocław.

The curative infrastructure of Długopole-Zdrój includes a few noteworthy structures, usually monuments, including: the "Dąbrówka" Spa Hospital (from 1819, one of the first spa buildings in Długopole-Zdrój. Until the 19th century it served as a Spa House with a hotel section, a treatment section and a dance hall and café. It was located along the first promenade. In the afternoons the spa orchestra would play right next to it. The structure underwent a general modernisation in 2011); the "Ondraszek" Spa Hospital (a comfortable sanatorium with 55 lodgings in double and triple rooms which underwent a complex renovation in 2000). The building is adapted to the needs of the disabled. It contains a hall for individual gymnastics and a local cryotherapy unit); the "Mieszko" Spa Hospital (raised in 1881 as the "Villa Urban," in the 1920s used by the Congregation of the Sisters of the Sacred Heart of Jesus); the "Fortuna" sanatorium (from 1830 on serving as a "bath facility" with rooms for treatment and the interior renovated in 1872 into a comfortable pension with 32 rooms. Currently, the sanatorium's former look and name have been restored); the "Zbyszko" recreational house (from 1826, reconstructed in 1881. It is a building very high as for the village standards, with a large viewing balcony facing the Wronki mountain. In its prewar, glory times it offered its guests 32 rooms, a renowned confectionery, a drug store and a Berlin Kampfmayer wine store. Renovated and adapted into 
the "Metalowiec" sanatorium after the second world war, the house currently functions as the private "Zbyszko" recreational centre). ${ }^{18}$

In regard of the village standards, the structures having a major role in the proper functioning of the spa also include the "Horus" café (1893), the "Zdrojowa" café (1840) and the post office (1876).

\section{Other and new functions in the spa town}

Contemporary times demand multifunctionality. A spa would prove noncompetitive and underdeveloped within market economy conditions when relying on an exclusively curative offer. That is why it is important to develop new functions that would attract not only patients, but the potential tourist in the broadest sense of the term.

The Przerzeczyn-Zdrój spa should make use of already functioning examples related to multifunctionality in other rural spas, e.g. Długopole-Zdrój or Solec-Zdrój ${ }^{19}$ as well as those found in small cities, e.g. Kudowa-Zdrój, PolanicaZdrój, Lądek-Zdrój in which extra-curative functions are becoming increasingly important. This involves the creation of renewal centres of the spa and wellness sort and centres for sports and recreation as well as sports-related and recreational facilities. The cultural potential of the village itself as well as its close vicinity has already been acknowledged. There is a number of touristically interesting structures in Przerzeczyn itself (providing possibilities for exploration) including: the 15th century Gothic parish church of the Black Madonna of Częstochowa, the Queen of Poland, transformed between 1729-33 into a baroque structure, with a mannerist altar from 1640, a baroque pulpit and organs from the 18th century;

18 E. Gonda-Soroczyńska, K. Przybyła, Możliwości i ograniczenia rozwoju uzdrowiska wiejskiego na przykladzie Dtugopola-Zdroju (The possibilities and limitations for the development of a rural spa using the example of Dlugopole-Zdrój), in: Podaż turystyczna jako determinanta ksztattowania popytu turystycznego (Tourist supply as a determinant of the development of tourist demand), Zeszyty Naukowe No. 701, Ekonomiczne Problemy Usług No. 86, Szczecin University, Szczecin 2012, pp. 249-264.

19 E. Gonda-Soroczyńska, Przestrzeń uzdrowiskowa w krajobrazie kulturowym wsi na przykładzie uzdrowiska Solec-Zdrój (Curative space in the cultural landscape of a village using the example of the Solec-Zdrój spa), Infrastruktura i Ekologia Terenów Wiejskich (Rural area infrastructure and ecology), Vol. 1, Polska Akademia Nauk, The Rural Technical Infrastructure Commission, Kraków 2011, pp. 39-49. 
renaissance and baroque epitaphs (the external walls contain one of the largest epitaph complexes in Silesia with 41 renaissance and baroque epitaphs from 1552-1617); a picturesque gorge of the river Ślęza with cascades, rapids and small waterfalls; a 19th century palace surrounded by the picturesque neo-renaissance landscape park; the historical city of Niemcza, Wojsławice near Niemcza with one of the most beautiful Polish arboretum (rhododendrons); the Tatarska Valley (a long gully stretching for a number of kilometers with a stream; the fortified settlement in Gilów).

The rich environmental values found in the entire Niemcza County may also be explored using delineated educational-environmental routes. One noteworthy example is the "Ligota Mała-Przerzeczyn Zdrój" Environmental-Educational Route and the "Dolina Tatarska" Environmental-Educational Route by the road leading from Niemcza to Dzierżoniów. ${ }^{20}$ Tourists and patients might also use a cycling route which starts at Przerzeczyn-Zdrój, i.e. the red route of Przerzeczyn Zdrój-Podlesie - Niemcza - Gilów - Piława Górna - Ligota Mała - Przerzeczyn Zdrój.

There is a number of tourist routes in the Owl Mountains and the NiemczaStrzelin Hills, two of which lead through the Niemcza municipality. These include the yellow and black tourist route.

The environmental-educational and cycling routes serve to show that other new functions that are extra-curative are slowly being introduced in the spa. Some additional new functions are to be expected following the construction of a new sanatorium-hospital complex, mainly those related to the services offered within.

The Długopole-Zdrój spa followed the path of spa and wellness. The luxurious SPA Medical Hospital "Elisa's Mansion” replaced the former sanatorium. The building is a monument from 1875-1876. It was on the brink of ruin in 1986 and had been sold to a private investor in 2005 , who sold it again to a private company in 2007. The new owner transformed the building into the new "Elisa's Mansion" SPA Medical Hotel combined with a well-equipped renewal centre.

The sports and recreation function is being developed as part of the multifunctional approach. There are centres in the town with sports structures at their disposal. One example is the "Relax" recreational centre or the "Silesia" vacation centre. Their visitors can use an indoor and outdoor swimming pool,

20 The Niemcza Municipality Tourist Information Booklet from 2012. 
a jacuzzi, a sauna, an exercise room, as well as sports fields for soccer, volleyball and basketball..$^{21}$

To summarize, one might say that the only prominent function in DługopoleZdrój is the curative function and the one pursued by the "Elisa's Mansion," which functions as a spa and wellness centre. There are lodgings available in pensions and single-family houses with no additional attractions. Certain establishments allegedly offering "agritourism" services in fact involve only accommodation, recreational equipment and a place to light a fire.

\section{Summary}

The development of tourism in the area of curative municipalities requires the realisation of goals established in the Tourism Development Strategy Project, which include: creating and developing competitive tourist products (ensuring the sufficient quantity and quality of natural resources for recreational and extra-recreational needs, especially water resources for the diverse manner of their utilization); formulating and implementing mechanisms and tools which influence the improvement of the quality of the tourist product; developing the infrastructure related to gastronomy and accommodation; developing the infrastructure related to tourist attractions; supporting the development of curative, medical, rehabilitative an wellness type tourism; supporting the development of agritourism. Agritourism in its broadest sense plays a significant role in social development and the activisation of rural areas. One should work towards increasing the dynamics of developing rural areas and diversifying them with the use of extra-agricultural activities pursued in these areas. Agritourism may become a specific, distinct form of tourism in the state, provided that the original cultural and environmental character of the Polish village is retained.

${ }^{21}$ E. Gonda-Soroczyńska, E. Przybyła, Możliwości i ograniczenia... 


\section{Final conclusions}

The following final conclusions have been drawn as a result of the conducted research:

1. Rural spa centres may be evaluated in the context of their attractiveness, similarly to those in small and large cities.

2. The (environmental) guidelines described in the study may be used for the purpose of conducting this evaluation.

3. Establishing a model for the attractiveness of rural spas would be essential in the evaluation of their attractiveness.

4. The attractiveness model for rural spas would be very helpful for potential future investors who might use it to draw the proper conclusions regarding the justification of pursuing certain investments.

5. Rural curative centres should ensure their development through the reconstruction and modernization of the curative infrastructure, the modernization of the technical infrastructure, the revitalization and enlargement of organized green areas, the introduction of spa multifunctionality, and by broadening their curative and touristic offer.

6. Rural spas showcasing extraordinary environmental potential (especially curative mineral waters and other curative materials) should improve their image and ensure that it is properly promoted and popularized.

7. The studied rural spas require the modernization of certain existing hospitals and sanatoriums. They also need to adjust all spa treatment structures to European Union standards, provide additional professional curative and rehabilitative equipment, modernize and improve the aesthetic condition of neglected structures related to supplementary spa treatment services, as well as modernize the existing heating systems.

\section{References}

Butler R.W., The concept of the tourism area cycle evolution: implications for management of resources, "The Canadian Geographers" 1980, Vol. 24/1.

Gaworecki W.W., Turystyka, Polskie Wydawnictwo Ekonomiczne, Warszawa 2003.

Gonda-Soroczyńska E., Przestrzeń uzdrowiskowa w krajobrazie kulturowym wsi na przykładzie uzdrowiska Solec-Zdrój, Infrastruktura i Ekologia Terenów Wiejskich, Vol. 1, Polska Akademia Nauk, The Rural Technical Infrastructure Commission, Kraków 2011. 
Gonda-Soroczyńska E., Przybyła K., Możliwości i ograniczenia rozwoju uzdrowiska wiejskiego na przykładzie Długopola-Zdroju, in: Podaż turystyczna jako determinanta kształtowania popytu turystycznego, Zeszyty Naukowe No. 701, Ekonomiczne Problemy Usług No. 86, Szczecin University, Szczecin 2012.

Gotowt-Jeziorska A., Wyrzykowski J., Turystyka a uzdrowiska, Polish Tourist Association, Warszawa 2005.

Hadzik A. et al., Konkurencyjność produktu turystyki uzdrowiska Kołobrzeg, Znaczenie innowacyjnych ustug i infrastruktury prozdrowotnej, Acta Scientiarum PolonorumOeconomia No. 9 (4), Tourism Experts Board, Warsaw University of Life Sciences, Warszawa 2010.

The Niemcza Municipality Tourist Information Booklet from 2012.

Iwanek T., Turystyka uzdrowiskowa w gospodarce regionu i kraju, Edukacja College of Management Publication House, "Monographs" - Joint Publications at the Edukacja College of Management in Wrocław, Wrocław 2006.

Januszewska M., Zróżnicowanie przestrzenne infrastruktury uzdrowiskowej na Dolnym Ślasku, Research Papers No. 967, Wrocław University of Economics, Wrocław 2002.

Kowalczyk A., Derek M., Zagospodarowanie turystyczne, Wydawnictwo Naukowe PWN, Warszawa 2010.

Kozłowska-Szczęsna T. et al., Bioklimat uzdrowisk polskich i możliwości jego wykorzystania w lecznictwie, PAN Institute of Geography and Spatial Organization, "Monograph" No. 3, Warszawa 2002.

Kruczek Z., Atrakcje turystyczne. Fenomen typologii, metody badań, "Monograph" No. 10, Proksenia, Kraków 2011.

Kruczek Z., Atrakcyjność turystyczna uzdrowisk karpackich, in: Uzdrowiska i ich funkcja turystyczno-lecznicza, "Monograph” No. 13, Proksenia, Kraków 2012.

Łazarek M., Łazarek R., Uzdrowiska w Europie. Teraźniejszość i rys historyczny, Vincent Pol University in Lublin Publishing House, Lublin 2007.

Mroczek-Czetwertyńska A., Rapacz A., Popyt na ustugi Spa \& Wellness i możliwości jego zaspokojenia na przykładzie Dolnego Śląska, University of Szczecin Research Bulletin, Economic issues related to Services No. 84, Tourist demand. Consumption-segmentation-markets, Szczecin 2012.

Mirek B., Przerzeczyn-Zdrój - o mojej wsi opowieść, Wrocław 2004.

Petryszyn J., Zuzańska-Żyśko E., Od funkcji przemysłowej do turystycznej-przykład Ustronia, $11^{\text {th }}$ Urban Knowledge Seminar, ed. I. Jażdżewska, Łódź University Publishing House, Łódź 2008.

Sallmann N., Megatrend wellness \& spa, PAG, Kraków 2011.

Soroczyńska A.M., Walory środowiskowe najmniejszego uzdrowiska $w$ Polsce, Przerzeczyna-Zdrój, Infrastruktura i Ekologia Terenów Wiejskich Vol. 10, Wyd. PAN, The Rural Technical Infrastructure Commission, Kraków 2011.

Szromek A.R., Rozwój obszarów turystycznych i uzdrowiskowych $w$ koncepcjach S.C. Ploga $i$ R. W. Butlera, The Silesian University of Technology Research Bulletins, Organisation and Management Section, Vol. 54, Gliwice 2010. 
Szromek A.R., Wskaźniki funkcji turystycznej. Koncepcja wskaźnika funkcji turystycznej i uzdrowiskowej, Silesian University of Technology Publishing House, Gliwice 2012.

Zuzańska-Żyśko E., Funkcja turystyczna małych miast województwa ślaskiego, in: Ksztattowanie funkcji turystycznych $w$ miejscowościach uzdrowiskowych, ed. E. Rydz, PAP, Słupsk 2005.

\title{
ATRAKCYJNOŚĆ TURYSTYCZNA UZDROWISK WIEJSKICH NA PRZYKŁADZIE PRZERZECZYNA-ZDROJU I DLUGOPOLA-ZDROJU
}

\begin{abstract}
Streszczenie
W przeprowadzonych badaniach dokonano próby oceny atrakcyjności wiejskich uzdrowisk na przykładzie dwóch dolnośląskich wsi, tj. Przerzeczyna-Zdroju i Długopola-Zdroju. Postawiono pytanie „Czy uzdrowisko wiejskie można oceniać w kontekście atrakcyjności podobnie jak miejskie? Jakie można zastosować wyznaczniki tej oceny? Wstępnie określono elementy decydujące o atrakcyjności uzdrowiska, wśród których wymieniono: usytuowanie uzdrowiska w kontekście ważnych ciągów komunikacji kołowej, kolejowej, autobusowej (dostępność komunikacyjna); usytuowanie topograficzne; klimat zdrowotny (leczniczy); występowanie leczniczych surowców (lecznicze wody mineralne, borowiny, inne); zabiegi lecznicze (rodzaje); miejsca noclegowe w sanatoriach, szpitalach uzdrowiskowych, hotelach, pensjonatach, motelach, zajazdach; pijalnie wód leczniczych; dom zdrojowy; tereny zielone (w tym Park Zdrojowy, lasy); amfiteatr; muszla koncertowa; Teatr Zdrojowy; restauracje, kawiarnie, bary, inne punkty gastronomiczne; atrakcje turystyczne; inne funkcje oprócz uzdrowiskowej; infrastruktura turystyczna poza uzdrowiskową; rodzaje leczonych schorzeń; spójność architektoniczno-urbanistyczna obiektów uzdrowiskowych; infrastruktura komunalna; jakość środowiska.
\end{abstract}

Słowa kluczowe: wieś, Przerzeczyn-Zdrój, Długopole-Zdrój, uzdrowisko, funkcja uzdrowiskowa, atrakcyjność, wielofunkcyjność 